\title{
Breaking Dormancy of "Tupy" Blackberry in Subtropical Conditions
}

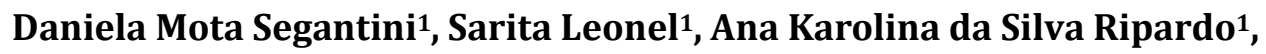 \\ Marco Antonio Tecchio', Manoel Euzebio de Souza2 \\ ${ }^{1}$ Departamento de Horticultura, Faculdade de Ciências Agronômicas, Universidade Estadual Paulista (UNESP), \\ Botucatu, Brasil \\ ${ }^{2}$ Departamento de Agronomia, Universidade Estadual de Mato Grosso (UNEMAT), Nova Xavantina, Brasil \\ Email: dani segantini@hotmail.com, sarinel@fca.unesp.br, karolinaagro@yahoo.com, tecchio@fca.unesp.br, \\ m.euzebio@unemat.br
}

Received 29 March 2015; accepted 21 July 2015; published 24 July 2015

Copyright (C) 2015 by authors and Scientific Research Publishing Inc.

This work is licensed under the Creative Commons Attribution International License (CC BY). http://creativecommons.org/licenses/by/4.0/

(c) (i) Open Access

\section{Abstract}

In subtropical or tropical conditions, the insufficient winter chill accumulation is often a limiting factor to break the dormancy of temperate-climate species such as the blackberry, which requires using products to help break dormancy. This study evaluates the efficacy of compounds in breaking dormancy of blackberry and its consequent influence on phenology and crop yields. The experiment was conducted in São Manuel, State of São Paulo, Brazil, in the 2011/2012 production cycle. The plants used were two-year-old "Tupy" blackberry (Rubus spp.), with $0.6 \times 4.0 \mathrm{~m}$ spacing (4.166 plants' $\mathrm{ha}^{-1}$ ). Pruning was performed in August, followed by the application of these treatments: control (water); hydrogen cyanamide (Dormex ${ }^{\circledR}$ ); nitrogen fertilizer (Erger ${ }^{\circledR}$ ) and mineral oil (Assist ${ }^{\circledR}$ ). The concentrations of each compound used were: $2.0 \%, 4.0 \%, 6.0 \%$ and $8.0 \%$. The compounds used influenced the budding, flowering and fruit harvest stages, in addition to providing increased yields depending on the concentration used. For hydrogen cyanamide the recommended concentration is of $4.2 \%$ and $\mathbf{5 . 4 \%}$ for nitrogen fertilizer; doses above these concentrations may cause phytotoxic effects. For mineral oil the dose recommended is of $8.0 \%$.

\section{Keywords}

Rubus spp., Phenology, Yield, Growth Regulator

\section{Introduction}

The increase of cultivated areas and the production of temperate fruits have grown in Brazil. On account of the

How to cite this paper: Segantini, D.M., Leonel, S., da Silva Ripardo, A.K., Tecchio, M.A. and de Souza, M.E. (2015) Breaking Dormancy of "Tupy" Blackberry in Subtropical Conditions. American Journal of Plant Sciences, 6, 1760-1767.

http://dx.doi.org/10.4236/ajps.2015.611176 
high market prices, health benefits and high antioxidant content of this fruit, the cultivation of blackberry has caught the interest of both producers and consumers in recent years [1] [2].

One of the obstacles to the advancement of these temperate fruits in subtropical and tropical climate regions regards the insufficient chilling hours. However, rustic varieties of peach, plum, pear, persimmon, fig and loquat have been successfully grown in warmer regions, with heat indices ranging between 40 and 80 hours (NHF < $7^{\circ} \mathrm{C}$ ) or 600 and 800 hours $\left(\mathrm{NHF}<13^{\circ} \mathrm{C}\right)$ in the state of São Paulo [3].

According to Takeda [4], winter temperatures affect induction, differentiation and consequently uniformity, flowering onset and duration of blackberries. In most cultivars the development and early elongation of inflorescence take place slowly, or not at all, throughout winter.

The natural break of dormancy of temperate species, such as blackberry, involves internal factors such as the balance between growth promoters and inhibitors, and external factors such as temperature, photoperiod, solar radiation, and other factors [5] [6]. According to Citadin [7], the accumulation of cold during winter is vital to break the dormancy of these species so that they sprout and bloom normally. An alternative to overcome this problem regards the use of compounds or techniques that simulate cold and also cultivars adapted to subtropical and tropical climate conditions.

Among the plant growth regulators to stimulate and standardize the budding and flowering of temperateclimate species, hydrogen cyanamide is one of the most widely used due to its high efficiency. Although this product is extremely effective for breaking dormancy of fruit plants, it is highly toxic and hazardous to the workers exposed to this substance, and a series of safety measures should be taken when applying this product. The U.S. Environmental Protection Agency (EPA) classifies Dormex ${ }^{\circledR}\left(490 \mathrm{~g} \cdot \mathrm{L}^{-1}\right.$ of $\mathrm{H}_{2} \mathrm{CN}_{2}$ ) at the highest toxicity category (category I). This high toxicity risk due to exposure to hydrogen cyanamide resulted in the temporary suspension of sales of the commercial product Dormex ${ }^{\circledR}$ in 2002 in Italy, and a regulatory review by European Union authorities [8]. The use of alternative products to hydrogen cyanamide is extremely important to sustainably expand temperate-climate fruit production. Low toxicity alternatives to hydrogen cyanamide have been evaluated for their efficacy to overcome dormancy of temperate-climate species, such as, nitrogen compounds, mineral oil, and garlic extract [9] [10].

According to Pérez [11], the presence of nitrogen compounds in products used to break dormancy, as for instance hydrogen cyanamide, caused respiratory stress, resulting in cell rearrangement and a ripple effect that could lead to breaking dormancy. Sagredo [12] reported that breaking the dormancy of buds using mineral oil was related to the presence of nitrogen compounds in its composition. The nitrogen fertilizer Erger ${ }^{\circledR}$ contains $15 \%$ nitrogen (present in organic, urea and nitrate forms) and 6.5\% calcium oxide (CaO) in its composition. Within this context, this study evaluates the influence of applying different doses of foliar fertilizer (Erger ${ }^{\circledR}$ ) and mineral oil (Assist ${ }^{\circledR}$ ) on breaking dormancy, phenology and yields of "Tupy" blackberry grown in regions with low occurrences of cold winter temperatures, using hydrogen cyanamide as a reference.

\section{Material and Methods}

The experiment was conducted at the São Manuel Experimental Farm, UNESP State University, Faculty of Agricultural Sciences, in the municipality of São Manuel, State of São Paulo, Brazil, SP, situated at 22 44'28"S and $48^{\circ} 34^{\prime} 37^{\prime \prime} \mathrm{W}, 740 \mathrm{~m}$ of altitude. According to the Köppen methodology the climate is Cfa (subtropical), with an average temperature above $22^{\circ} \mathrm{C}$ in the warmest month, small water deficiency in the months of April, July, and August, with annual potential evapotranspiration of $994.21 \mathrm{~mm}$, of which $33 \%$ was concentrated in the summer [13]. The region of Botucatu and São Manuel in the state of São Paulo has on average between 40 and 60 hours below $7.2^{\circ} \mathrm{C}$ and between 600 and 800 hours below $13^{\circ} \mathrm{C}$ [3]. The soil of the area is classified as redyellow Oxisol.

The two-year-old "Tupy" blackberry plants used were grown in a non-irrigated experimental area, conducted on four rods using the T trellis system, with 4 wires, and $1.2 \mathrm{~m}$ in height. The spacing used was $0.6 \mathrm{~m}$ between plants $\times 4.0 \mathrm{~m}$ rows $\left(4.166\right.$ plants $\left.\cdot \mathrm{ha}^{-1}\right)$.

The experimental design used was a $3 \times 5$ factorial scheme consisting of four compounds (Hydrogen Cyanamide, Nitrogen Fertilizer and Mineral Oil) in five concentrations (control, 2.0\%, 4.0\%, 6.0\% and 8 0\%) in 4 replicates in blocks, with the experimental plot consisting of five plants.

The commercial brands and the composition of each compound were as follows: Dormex ${ }^{\circledR}$ : hydrogen cyanamide (490 g. $\mathrm{L}^{-1} \mathrm{H}_{2} \mathrm{CN}_{2}$ ); Erger $^{\circledR}$ (monosaccharides and polysaccharides, 15\% total nitrogen, 5.8\% nitric nitro- 
gen, 3.1\% ammonia nitrogen, 6.1\% amidic nitrogen and 6.5\% calcium oxide, accompanied by $7 \%$ calcium sulfate) and Assist ${ }^{\circledR}$ (mineral oil $756 \mathrm{~g} \cdot \mathrm{L}^{-1}$ ).

The nitrogen fertilizer doses were composed of nitrogen fertilizer and calcium nitrate in their respective concentrations: control (water), $2.0 \%$ nitrogen fertilizer $+2.0 \%$ calcium nitrate, $4.0 \%$ nitrogen fertilizer $+4.0 \%$ calcium nitrate, $6.0 \%$ nitrogen fertilizer $+6.0 \%$ calcium nitrate and $8.0 \%$ nitrogen fertilizer $+8.0 \%$ calcium nitrate.

After pruning, on 08/17/2011, an average $250 \mathrm{~mL}$ of solution per plant were used in the application of different compounds to promote the breaking dormancy, which were painted one by one to prevent the solution from drifting.

The phenological phases were identified based on budding and flowering onset, respectively, $5 \%$ of vegetative buds were in the green tip stage and 5\% were open and producing flowering. The full budding and full bloom, respectively, when $50 \%$ or more of the vegetative buds were in the green tip stage, and when $50 \%$ of flowering buds were open. The end of each phenological stage was determined when there was no budding and vegetative buds or open flowers. The buds were counted in two stems of each plant, previously marked. The sprouting percentage was obtained using the following formula:

$$
\% \text { of sprouting }=(\text { germinated buds/vegetative buds }) \times 100
$$

The yield was determined by the kilos of fruit produced per plant and the stand of $4.166 \mathrm{pl} \cdot \mathrm{ha}^{-1}$.

The data were subjected to analysis of variance using the SAS Program SAS (1999). The average results of the different compounds were compared by the Tukey test at 5\% probability, and the polynomial regression analysis was performed for the concentrations of each compound.

\section{Results and Discussion}

At pruning-date (08/17/2011), the sum of the number of chilling hours below 7.2 and $13^{\circ} \mathrm{C}$ recorded in São Manuel_SP was 51.91 and 347.83 hours (Table 1), respectively, a number below that required for the Tupy cultivar, which requires approximately 215 hours below $7.2^{\circ} \mathrm{C}$ [14].

The plants treated with hydrogen cyanamide started sprouting 15 days after breaking dormancy, and 22 days after with foliar nitrogen fertilizer, regardless of the dose applied (Table 2). Hydrogen cyanamide has been reported by different authors as the most effective compound for breaking bud dormancy, for anticipation and standardization of budding, flowering and harvest. The application of nitrogen compounds such as Sodium Nitrate $\left(\mathrm{NaN}_{3}\right)$ and hydrogen cyanamide can cause respiratory and oxidative stress in the bud cells, which results incellular metabolic rearrangement, increasing ATP generation by glycolysis and fermentation, a necessary step for activating a cascade effect on the mechanism to break dormancy [11]. The presence of nitrogen in different forms in the composition of Erger ${ }^{\circledR}$ nitrogen fertilizer can lead to respiratory stress, such as with hydrogen cyanamide, accelerating the dormancy breaking process of the plants. It was found that with the increasing concentration of mineral oil, there was a higher onset of sprouting (Table 2). The composition of mineral oil has a mixture of paraffinic hydrocarbons, paraffinic cycle and saturated and unsaturated aromatics resulting from petroleum distillation, and its role in breaking bud dormancy is related to the presence of nitrogen compounds [12].

The flowering and harvesting peaks of plants treated with hydrogen cyanamide occurred, respectively, at 63 and 91 days after breaking dormancy, anticipating by 22 days the flowering peak and 52 days the harvest peak, compared with the control, independent of the concentration used (Table 2).

In plants treated with foliar nitrogen fertilizer $\left(\right.$ Erger $\left.^{\circledR}\right)$ the flowering peaks and harvest occurred, respectively, at 70 and 99 days after breaking dormancy, anticipating by 15 days the flowering peak and 44 days the harvest peak, compared with the control, independent of the concentration used. The mineral oil at concentrations of $6.0 \%$ and $8.0 \%$ provided higher anticipation of flowering and harvest peaks, when compared with the control (Table 2).

As for the harvest period, hydrogen cyanamide and nitrogen fertilizer were the most effective to standardize the collection period, reducing its interval from 74 to 50 days with cyanamide applied at $4.0 \%$; $6.0 \%$ and $8.0 \%$ and from 74 to 50 days with nitrogen fertilizer applied at $8.0 \%$ and 6.0\% (Table 2).

The results presented in this study are in agreement with Antunes [15], which evaluated the phenology of different blackberry cultivars in Rio Grande do Sul, without the use of plant growth regulators, and reported differences in harvest intervals due to the climatic conditions of every year, in 2003 a harvest interval of 30 days, in 2004 and 200564 and 63 days, respectively. 
Table 1. Number of chill hours below 7.2 and $13^{\circ} \mathrm{C}$, average minimum temperatures, average maximums, monthly averages and rainfall in São Manuel-SP, 2011.

\begin{tabular}{|c|c|c|c|c|c|c|}
\hline \multirow{2}{*}{ Months } & \multicolumn{2}{|c|}{ Chill hours accumulated } & \multicolumn{3}{|c|}{ Temperatures $\left({ }^{\circ} \mathrm{C}\right)$} & \multirow{2}{*}{ Rainfall (mm) } \\
\hline & $<7.2^{\circ} \mathrm{C}$ & $<13^{\circ} \mathrm{C}$ & Minimum & Maximum & Averages & \\
\hline January & 0.00 & 0.00 & 21.34 & 32.34 & 25.94 & 329.0 \\
\hline February & 0.00 & 0.00 & 21.40 & 32.74 & 26.17 & 289.0 \\
\hline March & 0.00 & 0.00 & 20.41 & 28.47 & 23.89 & 129.5 \\
\hline April & 0.00 & 0.00 & 19.59 & 29.56 & 23.76 & 43.5 \\
\hline May & 0.00 & 29.58 & 16.58 & 25.88 & 20.17 & 20.0 \\
\hline June & 39.58 & 156.58 & 14.91 & 24.42 & 18.67 & 50.0 \\
\hline July & 0.00 & 60.42 & 16.78 & 27.31 & 21.20 & 0.0 \\
\hline August & 12.33 & 101.25 & 16.63 & 28.70 & 21.79 & 4.0 \\
\hline September & 0.00 & 32.17 & 16.50 & 31.05 & 22.25 & 0.0 \\
\hline October & 0.00 & 147.08 & 18.48 & 29.53 & 23.05 & 16.5 \\
\hline November & 11.08 & 55.50 & 20.50 & 20.68 & 20.59 & 47.0 \\
\hline December & 0.00 & 0.00 & 22.46 & 22.66 & 22.56 & 121.0 \\
\hline
\end{tabular}

Data collected at the São Manuel experimental farm—SP, 2011.

Table 2. Number of days from pruning to the beginning, peak and end of budding, flowering and harvest of blackberry (Rubus spp.) plants of the Tupy cultivar treated with different promoter products to break gem dormancy (pruning on 08/17/ 2011). São Manuel, 2011/2012.

\begin{tabular}{|c|c|c|c|c|c|c|c|c|c|c|}
\hline \multirow{2}{*}{$\begin{array}{c}\text { Treatments } \\
\text { Hydrogen cyanamide }\end{array}$} & \multicolumn{3}{|c|}{$\begin{array}{c}\text { Budding } \\
\text { (days after pruning) }\end{array}$} & \multicolumn{3}{|c|}{$\begin{array}{c}\text { Flowering } \\
\text { (days after pruning) }\end{array}$} & \multicolumn{3}{|c|}{$\begin{array}{c}\text { Harvest } \\
\text { (days after pruning) }\end{array}$} & \multirow{2}{*}{$\begin{array}{c}\text { Harvest time } \\
\text { (Days) }\end{array}$} \\
\hline & Begin & Peak & End & Begin & Peak & End & Begin & Peak & End & \\
\hline Control & 36 & 56 & 69 & 59 & 85 & 121 & 99 & 143 & 163 & 74 \\
\hline $2.0 \%$ & 15 & 36 & 49 & 45 & 63 & 91 & 76 & 91 & 143 & 71 \\
\hline $4.0 \%$ & 15 & 36 & 49 & 45 & 63 & 91 & 76 & 91 & 123 & 50 \\
\hline $6.0 \%$ & 15 & 36 & 49 & 45 & 63 & 91 & 76 & 91 & 123 & 50 \\
\hline $8.0 \%$ & 15 & 36 & 49 & 45 & 63 & 91 & 76 & 91 & 123 & 50 \\
\hline Foliar nitrogen fertilizer & Onset & Peak & End & Onset & Peak & End & Onset & Peak & End & (Dias) \\
\hline Control & 36 & 56 & 69 & 59 & 85 & 125 & 99 & 143 & 163 & 74 \\
\hline $2.0 \%$ & 22 & 36 & 49 & 45 & 70 & 91 & 85 & 99 & 143 & 71 \\
\hline $4.0 \%$ & 22 & 36 & 49 & 45 & 70 & 91 & 76 & 99 & 123 & 71 \\
\hline $6.0 \%$ & 22 & 36 & 49 & 45 & 70 & 91 & 76 & 99 & 123 & 50 \\
\hline $8.0 \%$ & 22 & 36 & 49 & 45 & 70 & 91 & 76 & 99 & 123 & 50 \\
\hline Mineral oil & Onset & Peak & End & Onset & Peak & End & Onset & Peak & End & (Dias) \\
\hline Control & 36 & 56 & 69 & 59 & 85 & 125 & 99 & 143 & 163 & 74 \\
\hline $2.0 \%$ & 36 & 56 & 69 & 59 & 85 & 125 & 81 & 143 & 163 & 71 \\
\hline $4.0 \%$ & 29 & 56 & 69 & 59 & 85 & 125 & 80 & 143 & 163 & 71 \\
\hline $6.0 \%$ & 22 & 36 & 49 & 49 & 76 & 104 & 80 & 102 & 143 & 71 \\
\hline $8.0 \%$ & 22 & 36 & 49 & 49 & 76 & 104 & 80 & 102 & 143 & 71 \\
\hline
\end{tabular}

Mean values, based on the experimental design proposed in this paper.

With the increasing concentrations of hydrogen cyanamide and nitrogen fertilizer there was a quadratic increase in the percentage of sprouting buds, with maximum points, respectively, of $4.4 \%$ (93.1\% sprouted buds) and $6.8 \%$ (92.4\% sprouted buds). It was found that concentrations above $4.4 \%$ and $6.8 \%$ reduced the percentage of sprouted buds, which could indicate phytotoxic effect of very high concentrations of $\mathrm{CH}_{2} \mathrm{~N}_{2}$ and nitrogen fer- 
tilizer (Figure 1).

The results of this study highlight the need for using compounds to break dormancy of the "Tupy" blackberry cultivated in subtropical region and agree with reports found in the literature for temperate fruit trees grown in areas with low occurrences of cold temperatures.

In "Eva" apple trees an increase in budding percentages was observed up to a certain level, cyanamide at concentrations above $0.50 \%$ did not increase the sprouting percentage [16]. The application of Erger ${ }^{\circledR}$ at $7.0 \%+$ $\mathrm{Ca}\left(\mathrm{NO}_{3}\right) 7.0 \%$, a concentration close to that found in this study, promoted the highest bud sprouting percentage in "Gala" apple trees (70\%) and "Fuji Suprema" (68.5\%), whereas in the Controls budding was $12.8 \%$ for "Gala" and 30.3\% for "Fuji Suprema" [17].

In the "Superior Seedless" grapevines, subjected to $2 / 3$ of cold requirements $\left(300 \mathrm{~h}\right.$ below $5.0^{\circ} \mathrm{C}$ ), the hydrogen cyanamide application at $2.0 \%$ provided sprouting of $85 \%$ of buds, while the branches that did not receive the compound applications had only $40 \%$ of sprouted buds [18].

The effect of cyanamide on grapevine appears to be associated to respiratory stress conditions under oxygen deprivation conditions, given that soon after the hydrogen cyanamide application the activation of genes related to fermentative pathway was verified, and this indicates that respiratory stress caused by respiration inhibitors can activate the breaking of dormancy [19].

The linear regression model was adapted to express the increase in the percentage of sprouting buds using mineral oil, and using $8.0 \%$ concentration resulted in 79.15\% of budding (Figure 1). In "Hosui" pear trees, the mineral oil application promoted the increase in the number of buds, when compared with the control. The treatments using mineral oil at $4.0 \%$; $6.0 \%$ and $8.0 \%$ promoted, respectively, $72.02 \%$; $73.70 \%$ and $78.0 \%$ of sprouted buds, while the Control promoted the sprouting of 50.0\% of buds [20].

For the variables number of fruits per·plant ${ }^{-1}$ and yield $\left(\mathrm{t} \cdot \mathrm{ha}^{-1}\right)$, the quadratic regression models were adapted for the hydrogen cyanamide and nitrogen fertilizer, with maximum points of $4.2 \%\left(541 \mathrm{fruits}^{\mathrm{p}} \mathrm{pl}^{-1}\right.$ and $\left.14.7 \mathrm{t} \cdot \mathrm{ha}^{-1}\right)$ and 5.4\% (521 fruits $\cdot \mathrm{pl}^{-1}$ and $14.2 \mathrm{t} \cdot \mathrm{ha}^{-1}$ ) respectively. Higher concentrations than those mentioned above reduced the fruit production per-plant ${ }^{-1}$ and hence yields. With hydrogen cyanamide concentrations of $6.0 \%$ and $8.0 \%$, the yields were, respectively, 476.6 and 335.5 fruit $\cdot$ plant $^{-1}$, and the same nitrogen fertilizer concentrations provided 478.8 fruits and $506 \mathrm{pl}^{-1}$ respectively, showing a phytotoxic effect from using high concentrations of these compounds (Figure 2 and Figure 3).

Several authors have reported a decrease in the number of fruits in temperate-climate fruit trees due to the use of plant growth regulators at high concentrations. For "Imperial Gala" apple trees a dose of $7 \%$ of nitrogen fertilizer $\left(\right.$ Erger $^{\circledR}$ ) is recommended because above this threshold a decrease in fruit yields can occur due to phyto-

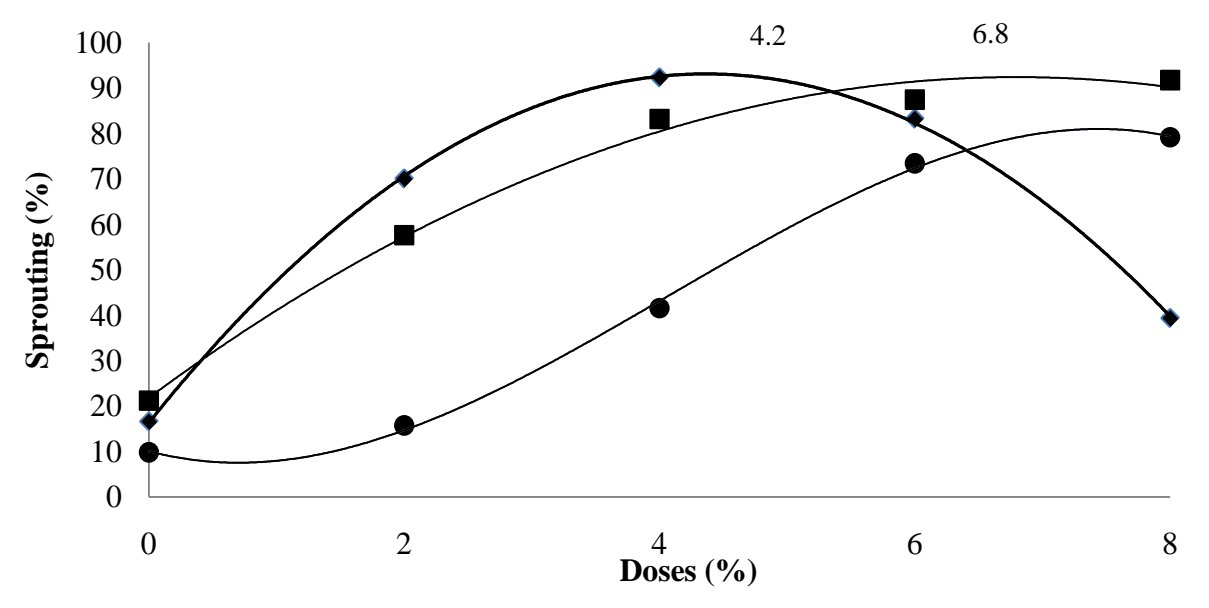

$$
\begin{aligned}
& \text { - Hydrogen cyanamide } \\
& y=-4.0352 x^{2}+35.213 x+16.281^{* *} \quad \mathrm{R}^{2}=0.9996 \\
& \text { - Nitrogen Fertilizer } \\
& y=-1.5264 x^{2}+20.755 x+21.829^{* *} \quad \mathrm{R}^{2}=0.9924 \\
& \text { - Mineral Oil } \\
& y=-0.4796 x^{3}+5.8552 x^{2}-7.4806 x+10.061^{* *} \mathrm{R}^{2}=0.9988
\end{aligned}
$$

Figure 1. Percentage of sprouted buds according to the compound doses used to break dormancy of the “Tupy” blackberry, in São Manuel—SP, 2012 ( ${ }^{* *}$ Significant at 5\% probability by the F test). 


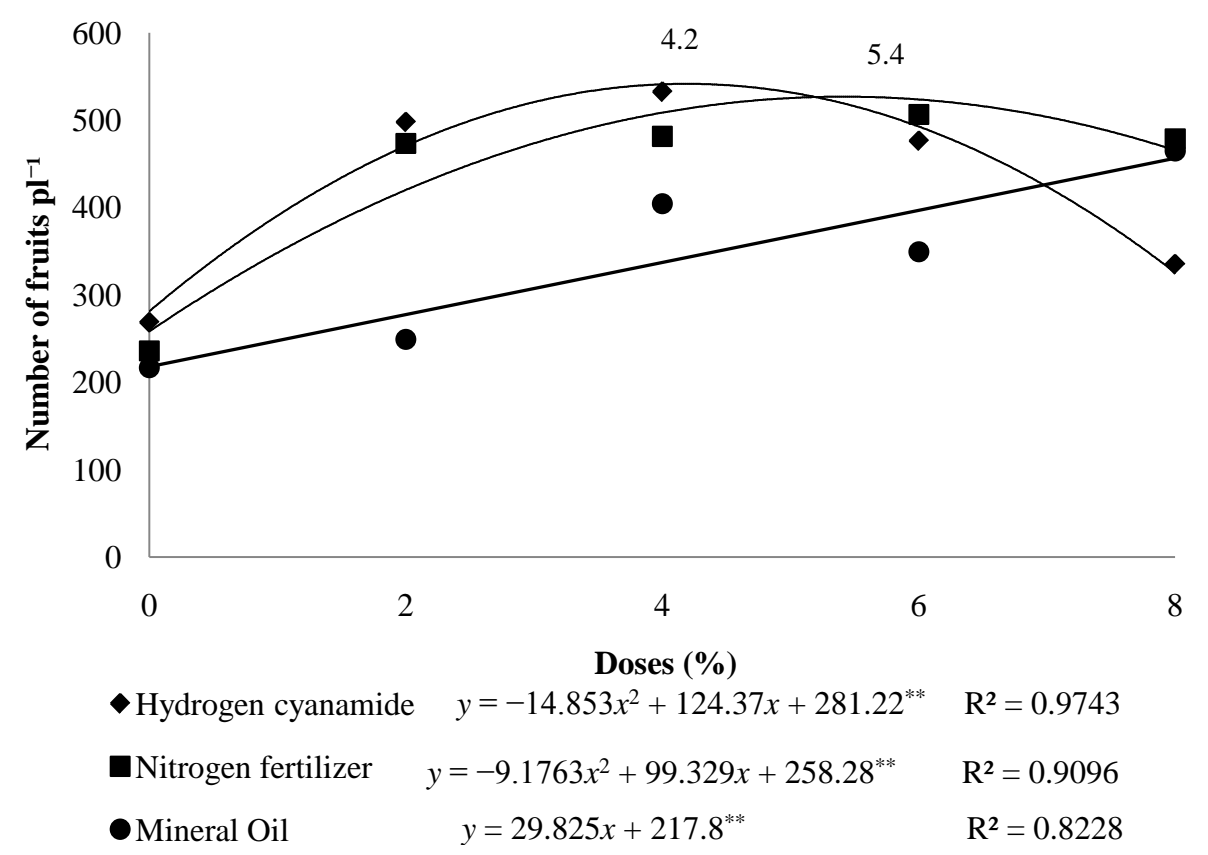

Figure 2. Number of fruits produced per plant according to the doses of compounds used to break dormancy of the “Tupy” blackberry, in São Manuel-SP, 2011/2012 ( ${ }^{* *}$ Significant at 5\% probability by the F test).

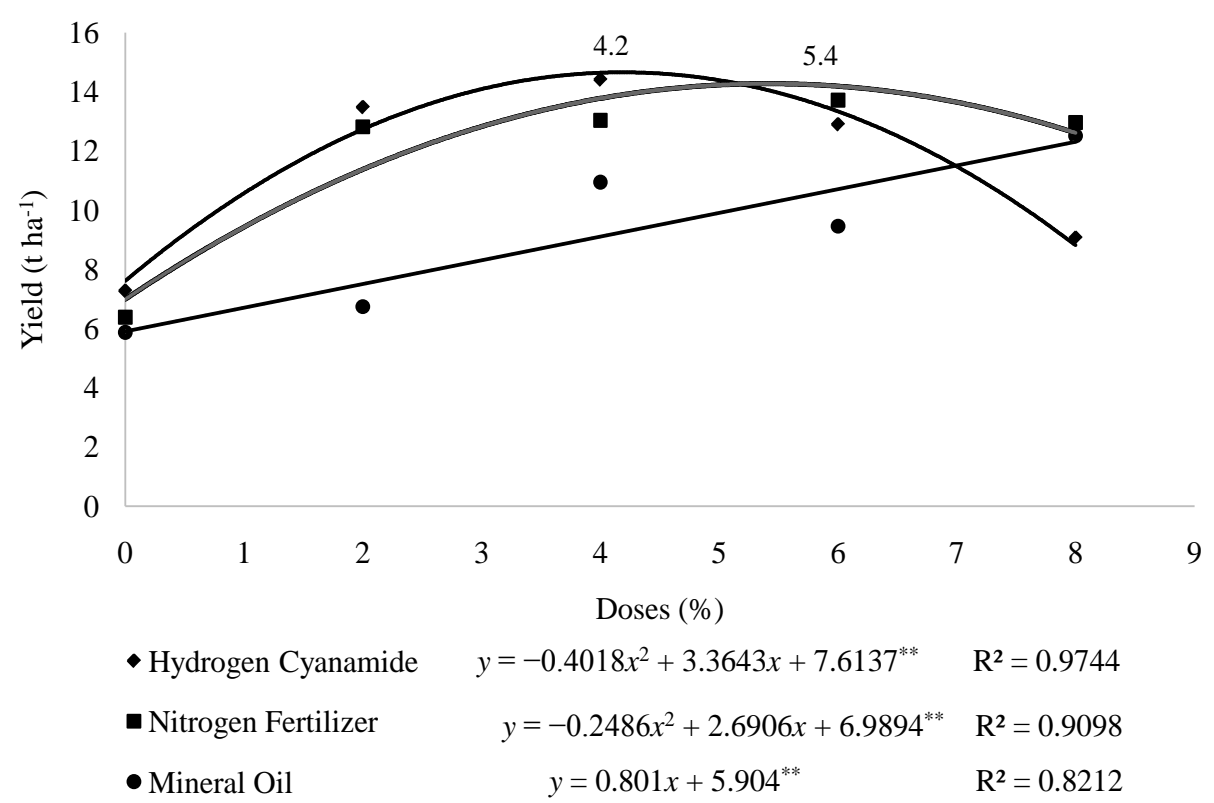

Figure 3. Tons of fruit per hectare according to the doses of the compounds used to break the dormancy of the "Tupy" blackberry in São Manuel-SP, 2011/2012 ( ${ }^{* *}$ Significant at 5\% probability by the F test).

toxic effects [21]. According to Coletti [22], the application of high concentrations of hydrogen cyanamide + mineral oil, in blueberries, reduced the number of fruit per plant, showing a phytotoxic effect of this combination on the concentration of $1.04 \%$ hydrogen cyanamide $+0.5 \%$ mineral oil.

The yield values verified in this study are similar to or higher than those found in the literature. Without the compound application the yields ranged from 5.9 to $7.3 \mathrm{t} \cdot \mathrm{ha}^{-1}$ (controls- $-0.0 \%$ concentration), and with the application the yields ranged from 6.7 to $14.4 \mathrm{t}^{-\mathrm{ha}^{-1}}$ (2.0\% mineral oil and 4.0\% hydrogen cyanamide) (Figure 3).

The application of mineral oil at different concentrations influenced the fruit yields per plant and the yields of blackberry, with the concentrations used the linear regression model was adapted, indicating that in the concen- 
trations used, as the concentration is increased there are increased yields, which was the highest yields achieved $\left(12.0 \mathrm{t}^{-h^{-1}}{ }^{-1}\right.$ ) when $8 \%$ mineral oil was used (Figure 3).

According to Antunes [23], under ideal cultivation conditions the blackberry can yield up to $10.0 \mathrm{t}^{\mathrm{h}} \mathrm{ha}^{-1}$. In our study it was found that without the use of dormancy-breaking compounds, the "Tupy" blackberry yielded on average $6.70 \mathrm{t}^{\mathrm{h}} \mathrm{ha}^{-1}$, a value close to that found by Antunes [15] of $5.169 \mathrm{t} \cdot \mathrm{ha}^{-1}$, in an agro-ecological farming system in the region of Pelotas-RS. But when $4.0 \%$ hydrogen cyanamide or $6.0 \%$ foliar nitrogen fertilizer was used to break dormancy the yields reached values of $14.4 \mathrm{t}^{\mathrm{h}} \mathrm{ha}^{-1}$ and $13.7 \mathrm{t} \cdot \mathrm{ha}^{-1}$, respectively (Figure 3). These differences demonstrate the influence of the cultivation system on the yield of the blackberry cultivar.

Under the conditions of Santa Helena-PR, subtropical climate region (Cfa), similar as in São Manuel, the yields of the "Tupy" blackberry, under different pruning times but without the application of plant growth regulators, ranged from 3.44 to $6.48 \mathrm{t} \cdot \mathrm{ha}^{-1}$ in 2008 and 0.86 to $6.25 \mathrm{t} \cdot \mathrm{ha}^{-1}$ in 2009 [24]. The yield differences between the two studies can be explained by executing the pruning in less favorable times and not using compounds to break dormancy of the plants.

The results presented in this study demonstrate the yield potential of the blackberry in subtropical conditions in the state of São Paulo, as well as the importance of using the adequate compound concentrations for breaking bud dormancy in these regions, since the temperate-climate plants do not have their required temperature fully satisfied, which affects their physiological processes and as a result affects their phenological phases and yields.

\section{Conclusions}

For hydrogen cyanamide the dose of $4.2 \%$ is recommended and for nitrogen fertilizer of $5.4 \%$, concentrations above these thresholds may have phytotoxic effects, resulting in lower fruit yields. For mineral oil a dose of $8.0 \%$ is recommended.

Nitrogen fertilizer showed similar results to hydrogen cyanamide and could be an alternative to this compound, since this product presented low risk to the workers applying this solution.

The use of adequate compounds to break dormancy of blackberry cultivars in areas with insufficient winter cold temperatures improves crop performance and increases yields.

\section{Acknowledgements}

The authors are grateful to FAPESP-State of São Paulo Research Foundation. Process No. 2010/52140-2, and to the agronomist Vitor Hugo Artigiani for kindly providing the Erger ${ }^{\circledR}$ product of Valagro.

\section{References}

[1] Kuskoski, E.M., Asuero, A.G., Morales, M.T. and Fett, R. (2006) Frutos tropicais silvestres e polpas de frutas congeladas: Atividade antioxidante, polifenóis e antocianinas. Ciência Rural, 36, 1283-1287. http://dx.doi.org/10.1590/S0103-84782006000400037

[2] Hassimoto, N.M.A., Mota, R.V., Cordenunsi, B.R. and Lajolo, F.M. (2008) Physico-Chemical Characterization and Bioactive Compounds of Blackberries Fruits (Rubus Sp.) Grown in Brazil. Ciência e Tecnologia de Alimentos, 28, 702-708. http://dx.doi.org/10.1590/S0101-20612008000300029

[3] Pedro Júnior, M.J., Ortolani, A.A., Rigitano, O., Alfonsi, R.R., Pinto, H.S. and Brunini, O. (1979) Estimativa de horas de frio abaixo de 7 e de $13^{\circ} \mathrm{C}$ para a regionalização da fruticultura de temperado no Estado de São Paulo. Bragantia, 38 , 123-130. http://dx.doi.org/10.1590/S0006-87051979000100013

[4] Takeda, F., Strik, B.C., Peacok, D. and Clark, J.R. (2002) Cultivar Differences and the Effect of Winter Temperature on Flower Bud Development in Black Mulberry. Journal of American Society Horticultural Science, 127, 495-501.

[5] Iuschi, V.L., Iuschi, T., Brighenti, E. and Ditrich, R. (2002) Quebra da dormência da macieira (Malus domestica Borkh) em São Joaquim-SC. Revista Brasileira de Fruticultura, 24, 168-174. http://dx.doi.org/10.1590/S0100-29452002000100037

[6] McArtney, S.J. and Walker, J.T.S. (2004) Current Situation and Future Challenges Facing the Production and Marketing of Organic Fruit in Oceania. Acta Horticulturae, 638, 387-396.

[7] Citadin, I., et al. (2006) Uso de cianamida hidrogenada e óleo mineral na floração, brotação e produção do pessegueiro “Chiripá”. Revista Brasileira de Fruticultura, 28, 32-35. http://dx.doi.org/10.1590/S0100-29452006000100012

[8] Settimi, L., Davanzo, F., Faraoni, L., Miceli, G., Richmond, D. and Calvert, G.M. (2005) Update: Hidrogen Cyanamide-Related Ilnesses-Italy, 2002-2004. Morbidity and Mortality Weekly Report, 54, 405-408. 
[9] Botelho, R.V. (2007) Efeito do extrato de alho na quebra de dormência de macieiras. Revista Brasileira de Fruticultura, 29, 403-405. http://dx.doi.org/10.1590/S0100-29452007000200042

[10] Botelho, R.V. (2008) Uso de bioestimulante para a quebra de dormência de macieira cv. Castel gala. Scientia Agraria, 9, 399-403. http://dx.doi.org/10.5380/rsa.v9i3.11706

[11] Pérez, F.J., Vergara, R. and Or, E. (2009) On the Mechanism of Dormancy Release in Grapevine Buds: A Comparative Study between Hydrogen Cyanamide and Sodium Azide. Plant Growth Regulation, 59, 145-152. http://dx.doi.org/10.1007/s10725-009-9397-5

[12] Sagredo, K.S., Theron, K.I. and Cook, N.C. (2005) Effect of Mineral Oil and Hydrogen Cyanamide Concentration on Dormancy Breaking in “Golden Delicious” Apple Trees. South African Journal of Plant and Soil, 22, 251-256. http://dx.doi.org/10.1080/02571862.2005.10634716

[13] Cunha, A.R. and Martins, D. (2009) Classificação climática para os municípios de Botucatu e São Manuel, SP. Irriga, $14,1-11$

[14] Silveira, T.M.T., Raseira, M.C.B., Couto, M. and Einhardt, P. (2007) Necessidade em horas de acúmulo de frio em três cultivares de amoreira-preta. In: Congresso de Iniciação Científfica, Pelotas, 16. http://www.ufpel.tche.br/cic/2007/cd/pdf/CA/CA_01512.pdf

[15] Antunes, L.E.C., Gonçalves, E.D. and Trevisan, R. (2010) Fenologia e produção de cultivares de amoreira-preta em sistema agroecológico. Ciência Rural, 40, 1929-1933. http://dx.doi.org/10.1590/S0103-84782010000900012

[16] Roberto, S.R., Kagueyama, M.H. and Santos, C.D. (2006) Indução da brotação da macieira “Eva” em região de baixa incidência de frio. Revista Brasileira de Fruticultura, 28, 128-130. http://dx.doi.org/10.1590/S0100-29452006000100035

[17] Hawerroth, F.J., Petri, J.L., Leite, G.B. and Herter, F.G. (2010) Brotação de gemas em macieiras "Imperial Gala” e “Fuji Suprema” pelo uso de Erger ${ }^{\circledR}$ e nitrato de cálcio. Revista Brasileira de Fruticultura, 32, 343-350. http://dx.doi.org/10.1590/S0100-29452010005000074

[18] Mohamed, H.B., Vadel, A.M., Geuns, J.M.C. and Khemira, H. (2012) Effects of Hydrogen Cyanamide on Antioxidant Enzymes' Activity, Proline and Polyamine Contents during Bud Dormancy Release in Superior Seedless Grapevine Buds. Acta Physiologiae Plantarum, 34, 429-437. http://dx.doi.org/10.1007/s11738-011-0839-0

[19] Vergara, R., Rubio, S. and Pérez, F.J. (2012) Hypoxia and Hydrogen Cyanamide Induce Bud-Break and Up-Regulate Hypoxic Responsive Genes (HRG) and VvFT in Grapevine-Buds. Plant Molecular Biology, 79, 171-178. http://dx.doi.org/10.1007/s11103-012-9904-3

[20] Oliveira, O.R., Peressuti, R.A., Skalitz, M.C.A., Biasi, L.A. and Zanete, F. (2008) Quebra de dormência de pereira "Hosui” com uso de óleo mineral em dois tipos de condução. Revista Brasileira de Fruticultura, 30, 409-413. http://dx.doi.org/10.1590/S0100-29452008000200024

[21] Hawerroth, F.J. (2010) Cianamida hidrogenada, óleo mineral e vegetal na brotação e produção da macieira "Royal Gala”. Semina: Ciências Agrárias, 31, 383-387.

[22] Coletti, R., Nienow, A.A. and Calvete, E.O. (2011) Superação da dormência de cultivares de mirtileiro em ambiente protegido com cianamida hidrogenada e óleo mineral. Revista Brasileira de Fruticultura, 33, 685-690. http://dx.doi.org/10.1590/s0100-29452011005000054

[23] Antunes, L.E.C. (2002) Amora-preta: Nova opção de cultivo no Brasil. Ciência Rural, 32, 151-158. http://dx.doi.org/10.1590/s0103-84782002000100026

[24] Campagnolo, M.A. and Pio, R. (2011) Produção da amoreira-preta “Tupy” sob diferentes épocas de poda. Ciência Rural, 42, 225-231. http://dx.doi.org/10.1590/S0103-84782012005000007 